\title{
MODELING ALTERNATIVES FOR EROSION CONTROL AT MATAGORDA COUNTY, TEXAS, WITH GENCADE
}

\author{
Ashley E. Frey ${ }^{1}$, James Rosati III', Kenneth J. Connell ${ }^{2}$, Hans Hanson ${ }^{3}$ and Magnus Larson ${ }^{3}$
}

\begin{abstract}
Matagorda Peninsula and Sargent Beach, Texas, USA, have experienced some of the highest rates of erosion along the Texas coast. In order to increase protection from tropical events and slow beach habitat erosion, several structural alternatives were studied. These alternatives were modeled with GenCade, a newly developed 1D shoreline change and sand transport model. GenCade was calibrated and validated over the 60 miles of shoreline in Matagorda County. Then separate GenCade grids and simulations were conducted for the structural alternatives at Matagorda Peninsula and Sargent Beach. At Matagorda Peninsula, different groin lengths and spacing between groins were modeled with and without beach fills and mechanical bypassing. The alternatives at Sargent Beach included detached breakwaters, groins, and beach fills. Although the process described in this paper only includes a small part of a more detailed study, these simulations helped lead to a recommendation of the selected alternatives for preliminary engineering design.
\end{abstract}

Keywords: GenCade; numerical modeling; shoreline change; sand transport; Matagorda County

\section{INTRODUCTION}

This paper describes modeling structural alternatives as part of a larger study that centers on alternatives and preliminary engineering design to protect the beaches of Matagorda County, Texas. Although much of the county has experienced erosion historically, the two regions of concern are a short stretch of beach located on Matagorda Peninsula and the Sargent Beach area. The region on Matagorda Peninsula consists of a 2.5 mile long stretch between the Mouth of the Colorado River (MCR) and 3 Mile Cut. Jetties were constructed at MCR between 1988 and 1990 (Kraus et al. 2008), and a new east jetty was completed in October 2010. The region on Matagorda Peninsula has also been historically breached by ephemeral inlets. It is necessary to develop a structural solution that will reduce damage from storms, protect the beach habitat, and reduce sediment impoundment along the new MCR east jetty. Sargent Beach is one of the fastest eroding beaches on the Texas coast (Stauble et al. 1994). A revetment was built in 1998 to protect Sargent Beach and the Gulf Intracoastal Waterway (GIWW). If the revetment was not constructed, the beach habitat would have been lost, and a breach due to chronic erosion could have occurred and stalled traffic on the GIWW. Although the revetment protects Sargent Beach and the GIWW, several sections are now exposed to wave action. It is expected that nearly the entire shoreline will recede to the revetment in the next five years. Figure 1 highlights the areas of interest on the Texas coast.

This study aims to simulate several structural alternatives with GenCade at each area of concern. In the preliminary study (Thomas and Dunkin 2012), a variety of structural alternatives were simulated at Matagorda Peninsula. Based on the findings in that study, only groin alternatives of varying lengths and distances apart are simulated at Matagorda Peninsula. The main goals of the final project are to increase the dry beach width, stabilize the beach between 3 Mile Cut and MCR, and not impact the shoreline change rates at 3 Mile Cut. In addition to several structural alternatives, different mechanical bypassing rates and beach fill quantities are included in some of the model simulations. A wider variety of alternatives are simulated at Sargent Beach. Groins, beach fills, and detached breakwaters are simulated. The breakwater simulations include different numbers of breakwaters, alongshore locations, breakwater lengths, breakwater spacing, and distances offshore. This GenCade modeling study consists of one part of a larger study which also includes additional modeling and preliminary engineering design. Phase 1 of the study which included site conditions, a conceptual sediment budget, and preliminary alternatives is described in Thomas and Dunkin (2012). The GenCade modeling of structural alternatives was one piece of the study that led to selection of the alternatives chosen for the preliminary engineering design.

It should be mentioned here that the locations of concern for this project are very complex. Due to cross-shore transport and the presence of cohesive sediments at Sargent Beach, no model alone could accurately predict shoreline change or longshore transport for breakwater alternatives. Therefore, an

\footnotetext{
${ }^{1}$ U.S. Army Engineer Research and Development Center, Coastal and Hydraulics Laboratory, 3909 Halls Ferry Rd., Vicksburg, MS, USA 39180

${ }^{2}$ Golder Associates, Inc., 18300 NE Union Hill Road, Suite 200, Redmond, WA, USA 98052

${ }^{3}$ Lund University, Department of Water Resources Engineering, Box 118, S-221 00, Lund, Sweden
} 
adaptive and qualitative approach was conducted. GenCade, CMS-Wave (Lin et al. 2008, Lin et al. 2011), and empirical calculations were used together to predict the effects of the breakwaters. Although this paper only describes the numerical modeling with GenCade, the model alone could not be used on a project with complexities similar to Sargent Beach and the breakwaters alternatives.

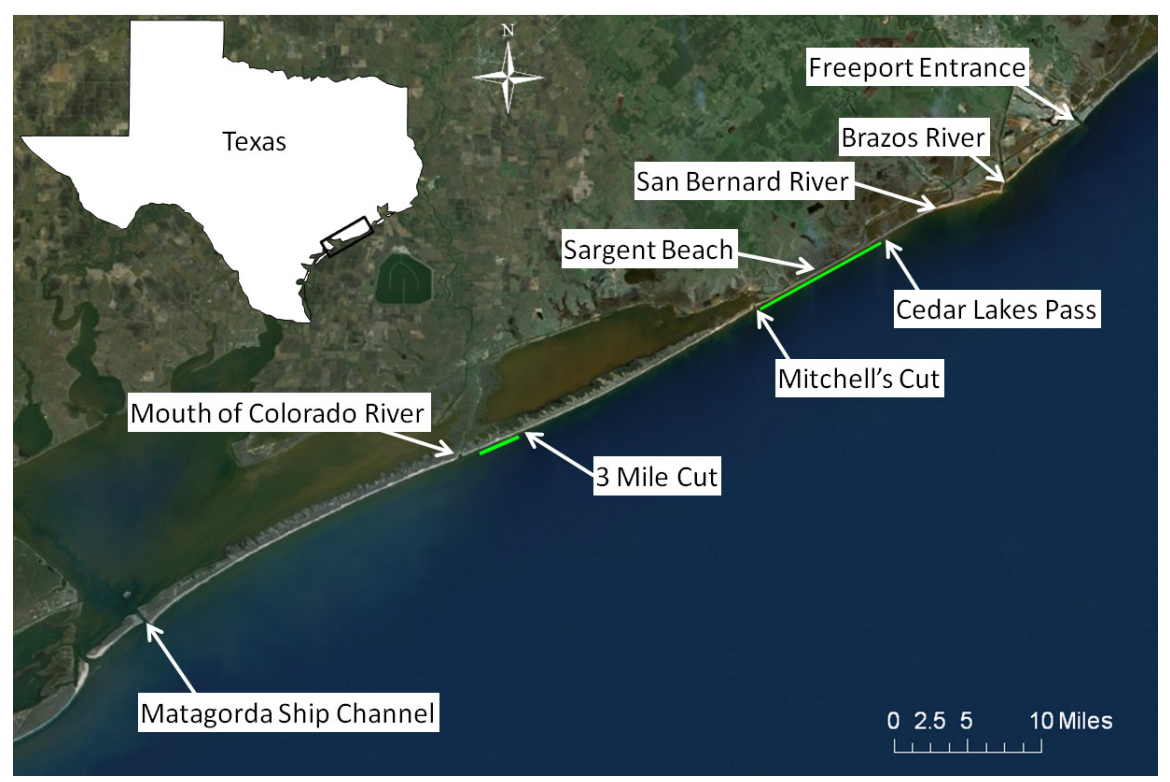

Figure 1. Map of region (areas of interest shaded in green).

\section{GENCADE}

GenCade (Hanson et al. 2011) is a 1D shoreline change and sand transport model jointly funded by the Coastal Inlets Research Program and Regional Sediment Management Program of the U.S. Army Engineer Research and Development Center. It is based on the combination of GENESIS (Hanson and Kraus 1989), a project-scale, engineering-design level model, and Cascade (Larson et al. 2003, Larson et al. 2006) a regional-scale, planning-level model. GenCade calculates wave-induced longshore sand transport, natural bypassing morphology and morphology change at inlets through a simplified version of the Inlet Reservoir Model (IRM) (Kraus 2002), and shoreline change on scales over several years to multiple decades. Structures like groins, seawalls, and breakwaters; engineering activities such as beach fills and dredging; inlets; shorelines; and wave gauges can be represented in GenCade. Variable grid spacing has also been implemented to decrease computational time necessary for simulations on a more regional scale.

GenCade is run in the Surface-Water Modeling System (SMS) 11.1. The SMS provides intuitive interfaces, georeferencing capabilities, and quality graphics. Two separate interfaces are used to set up and run GenCade: the conceptual model and the GenCade model. Georeferenced aerial photos and shorelines may be opened in the conceptual model while seawalls, revetments, groins, beach fill events, inlets with shoal volumes and dredging, and wave gauge information may be created and input to GenCade. After all of the information for a case is defined, the map in the conceptual model is converted to a 1D GenCade grid in the GenCade model. In the GenCade model, all of the locations of features are converted to cell numbers. Following a GenCade simulation, output files for shoreline position, inlet shoal volume change, net transport, and left and right directed transport can be opened and viewed.

\section{METHOD AND CALIBRATION}

The GenCade model was calibrated from the San Bernard River to the Matagorda Ship Channel for the 1995 to 2000 time period. The grid contains a total of 655 cells ranging in size from $130 \mathrm{ft}$ to $490 \mathrm{ft}$ with the smaller cell size necessary near inlets. The total length of the grid is 54.75 miles.

In its simplest form, GenCade requires an initial shoreline, time series of directional waves, initial and equilibrium volumes for each of the shoals at an inlet, and values specified for numerous 
parameters. The 1995 shoreline (Bureau of Economic Geology 2011) was smoothed and applied as the initial shoreline in GenCade. The initial and equilibrium shoal volumes were estimated based on aerial photographs and were calculated when data were available. Data from the Wave Information Study (Wave Information Studies 2011) were applied for the 1995 to 2000 time period. Four WIS stations with water depths ranging from 59 to $62 \mathrm{ft}$ were used for the calibration. The average berm height was 4 $\mathrm{ft}$, the average depth of closure was $19.7 \mathrm{ft}$, and the effective grain size was determined to be $0.2 \mathrm{~mm}$. The left and right boundary conditions were specified as moving based on the measured shoreline change in the region over the five year period. Mitchell's Cut and MCR were specified as inlets and the Sargent Beach revetment and MCR jetties were input in the model as structures.

Figure 2 compares the calculated transport rates to the measured rates. Southwest of Mitchell's Cut, the calculated net transport rates correspond to the measured rates. The net transport rates calculated are slightly greater than the measured rates at Sargent Beach, but the calculated rates are lower than the measured rates from the northeastern grid boundary to near Cedar Lakes Pass.

The model was calibrated with the 1995 and 2000 shorelines. The calculated shoreline change after five years reasonably compares to the measured shoreline (Figure 3). The model predicts accretion southwest of MCR although erosion occurred, but since this region does not affect the areas of modeling alternatives, this was not investigated further.

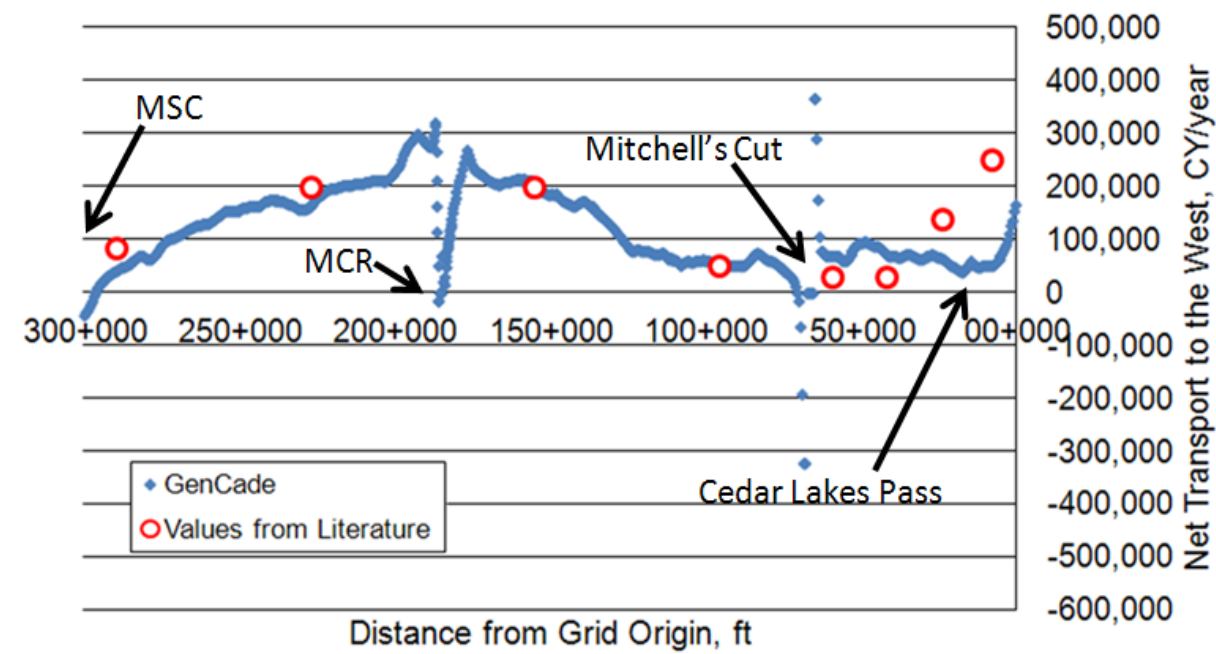

Figure 2. Calculated model results versus published results for net transport.

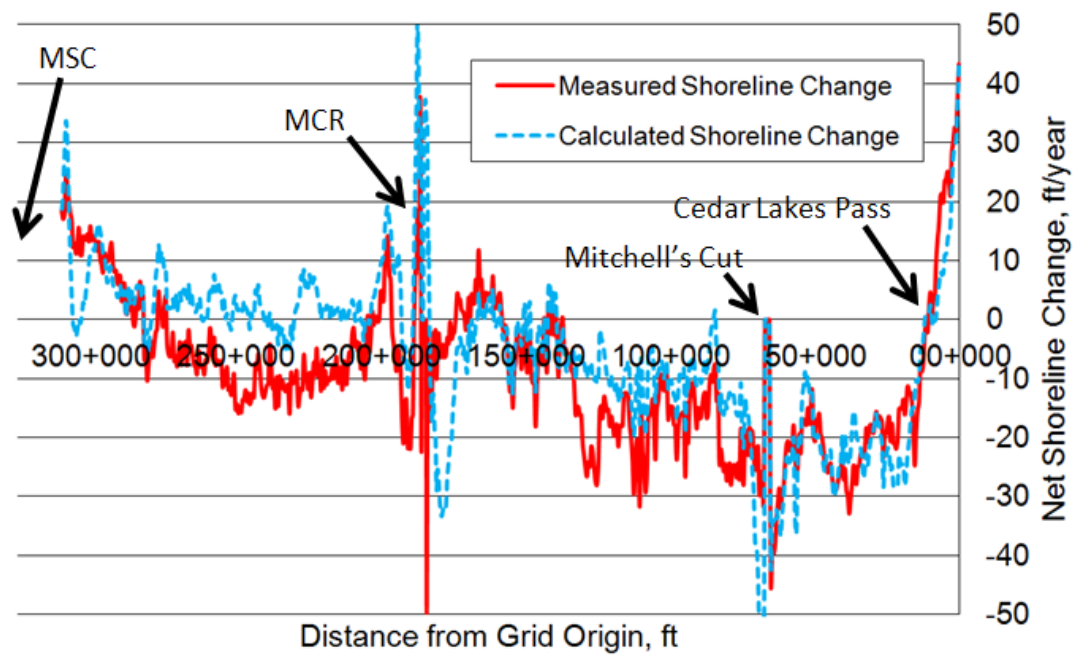

Figure 3. Calculated versus measured shoreline change. 


\section{MODELING ALTERNATIVES}

\section{Matagorda Peninsula}

The main goals of the structural alternatives are to halt erosion and increase the beach width over the 2.5 mile project area. The GenCade grid was shortened, so that it only includes the section of the shoreline related to the alternatives. The model domain extends from about 3.3 miles southwest of Mitchell's Cut to about 8.7 miles southwest of MCR and is 28 miles long. The grid contains 502 cells which range from 75 to $490 \mathrm{ft}$. The smallest cells are located between 3 Mile Cut and just southwest of MCR to give additional detail near the groins and the inlet. Since the grid is shorter than the one used for the calibration, only two WIS hindcast stations were necessary. During preliminary modeling, it was determined that a single groin would not adequately meet the project goals (Thomas and Dunkin 2012). Therefore, the existing condition and a set of ten alternatives are modeled. Table 1 lists the groin lengths and spacing for each alternative. The first groin for all of these alternatives is located about 2,500 ft southwest of 3 Mile Cut. Alternative 1 consists of the most groins (seven), while Alternative 5 consists of the least (three). After a five year simulation, all of these alternatives result in significant shoreline change at 3 Mile Cut. Since this does not meet the project goals, the groin field in each alternative was shifted 1,640 to the southwest. These shifted alternatives, which are noted in Table 1, retain the same configuration as the initial alternatives but are located closer to MCR. Beach fills are not included in any of the alternatives described in Table 1; however, beach fill quantities are simulated for the recommended alternative. A mechanical bypassing rate of 115,000 cubic yards per year is specified in GenCade. Although mechanical bypassing was recommended in Kraus et al. (2008), adequate funds may not be available. Therefore, bypassing rates ranging from 0 to 200,000 cubic yards per year are simulated for the selected alternative.

\begin{tabular}{|c|c|}
\hline \multicolumn{2}{|r|}{ Table 1. List of MCR Alternatives } \\
\hline Alternative & Description \\
\hline Alternative 0 & No action, no groins constructed \\
\hline Alternative 1 & $\begin{array}{l}7 \text { groins, } 400 \mathrm{ft} \text { long, } 800 \mathrm{ft} \text { apart (last } 3 \text { groins are shorter and closer together), } \\
\text { First groin approximately 2,500 ft southwest of } 3 \text { Mile Cut }\end{array}$ \\
\hline Alternative 1 - Shifted & Same as Alternative 1, Groins shifted 1,640 ft to the southwest \\
\hline Alternative 2 & $\begin{array}{l}5 \text { groins, } 400 \mathrm{ft} \text { long, 1,200 ft apart (last } 2 \text { are shorter and closer together), First } \\
\text { groin 2,500 ft southwest of } 3 \text { Mile Cut }\end{array}$ \\
\hline Alternative 2 - Shifted & Same as Alternative 2, Groins shifted $1640 \mathrm{ft}$ to the southwest \\
\hline Alternative 3 & $\begin{array}{l}5 \text { groins, } 600 \mathrm{ft} \text { long, 1,200 ft apart (last } 2 \text { are shorter and closer together), First } \\
\text { groin } 2,500 \mathrm{ft} \text { southwest of } 3 \text { Mile Cut }\end{array}$ \\
\hline Alternative 3 - Shifted & Same as Alternative 3, Groins shifted $1640 \mathrm{ft}$ to the southwest \\
\hline Alternative 4 & $\begin{array}{l}5 \text { groins, } 600 \mathrm{ft} \text { long, 1,800 ft apart (last } 2 \text { are shorter and closer together), First } \\
\text { groin 2,500 ft southwest of } 3 \text { Mile Cut }\end{array}$ \\
\hline Alternative 4 - Shifted & Same as Alternative 4, Groins shifted 1,640 ft to the southwest \\
\hline Alternative 5 & 3 groins, $800 \mathrm{ft}$ long, 1,600 ft apart \\
\hline Alternative 5 - Shifted & Same as Alternative 5 , Groins shifted $1,640 \mathrm{ft}$ to the southwest \\
\hline
\end{tabular}

Alternatives 1-5 after five years are shown in Figure 4. Figure 5 shows Alternatives 1-5 Shifted after five years. Alternative 0 is plotted in both figures. The black line at approximately $86+000 \mathrm{ft}$ represents 3 Mile Cut, and the black line at about $102+000 \mathrm{ft}$ is MCR. The black, dashed lines represent the initial positions of the groins in Alternative 1 . The plot became too difficult to read when the locations of the groins for the other alternatives were shown, so they were removed. Alternative 5 results in the most accretion to the northeast of the first groin in both the initial and shifted simulations while Alternative 2 results in the least accretion. The shoreline at 3 Mile Cut is nearly stationary for Alternative 0 , but the accretion ranges from 18 to $36 \mathrm{ft}$ and 9 to $17 \mathrm{ft}$ over the five year simulation for the initial and shifted structural alternatives, respectively. Alternatives 3 and 5 predict the most erosion to the southwest of the last groin for the initial alternatives. Alternative 3 predicts the most erosion for the shifted cases. All of the alternatives predict more erosion than Alternative 0 from about $93+000$ to $101+000 \mathrm{ft}$, but the calculated shorelines for Alternative 0 and the other alternatives are nearly identical to the southwest of MCR. 


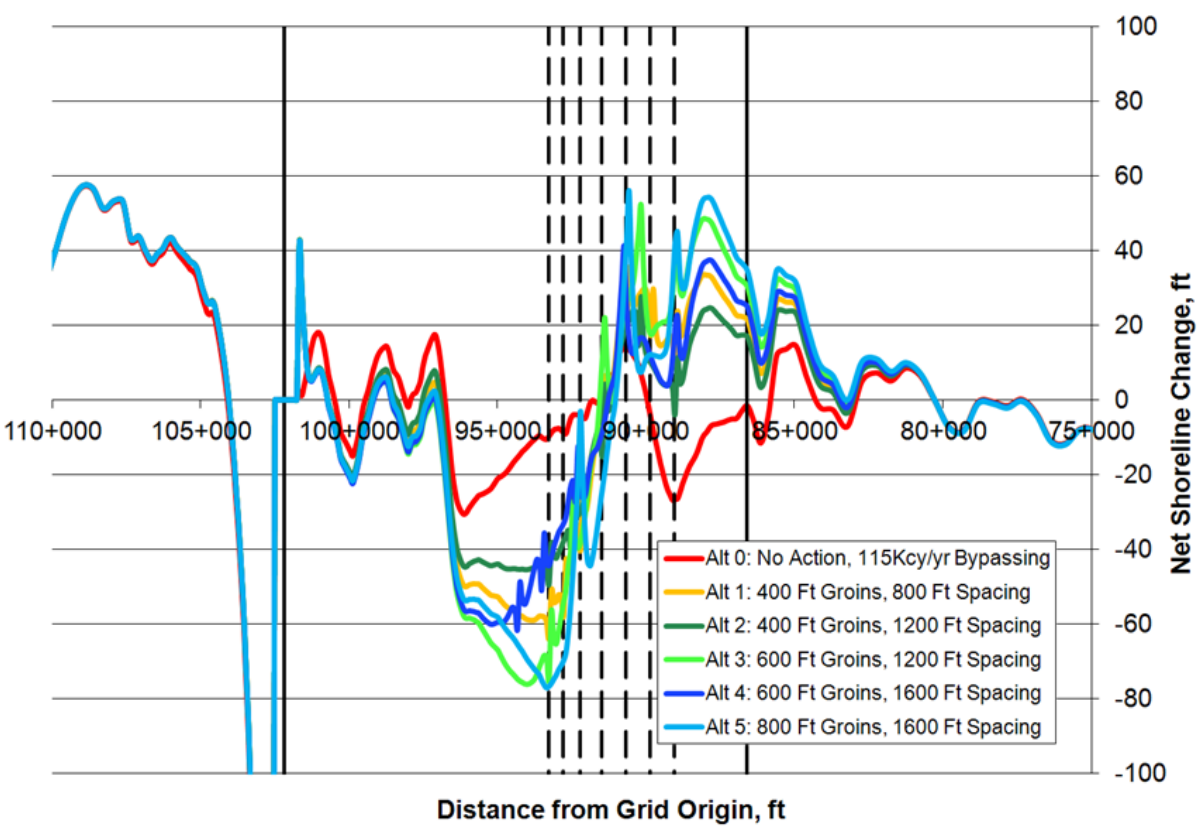

Figure 4. Shoreline change for Alternatives 1-5 after five years.

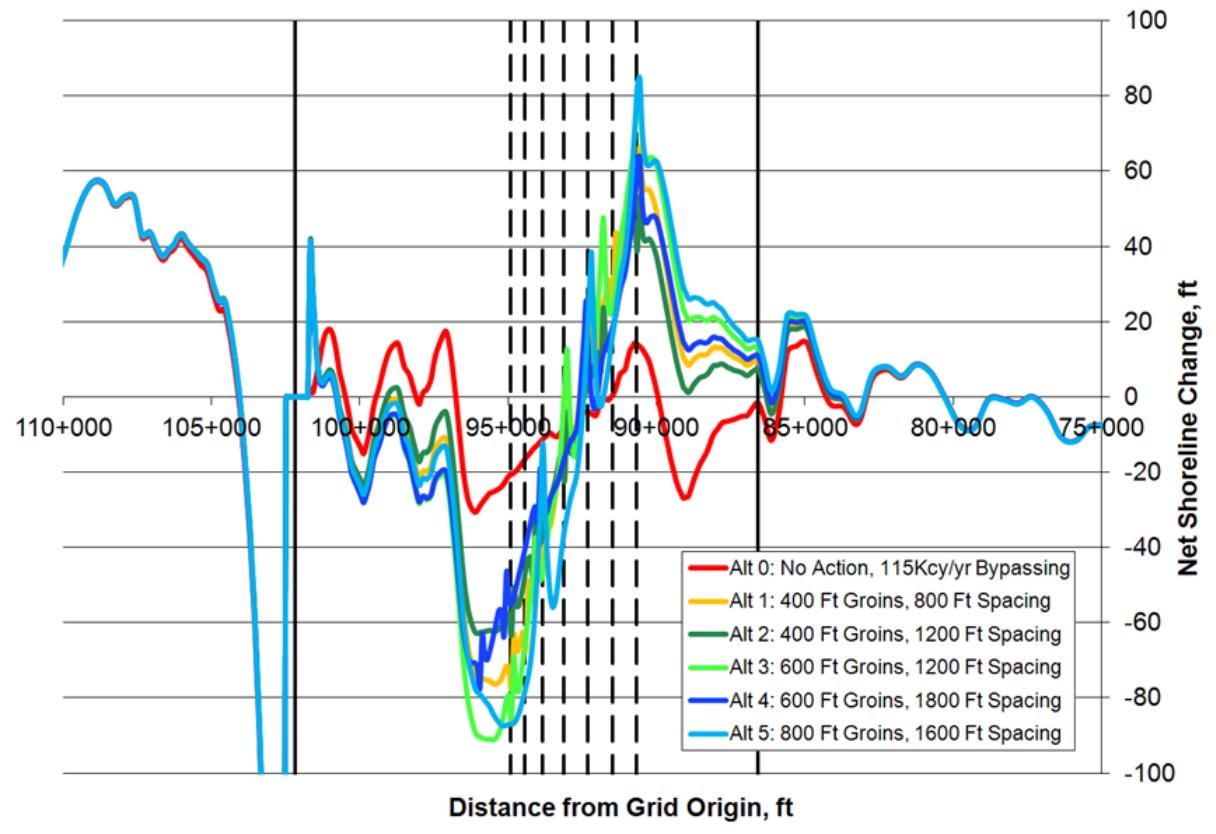

Figure 5. Shoreline change for Alternatives 1-5 Shifted after five years.

Sixteen year simulations were also conducted. WIS does not have hindcast data available for 20002011, so the waves from 1990 to 1999 were repeated for the missing years. Initially, the 1995 shoreline position was chosen as the initial shoreline, and the final calculated shoreline after 16 years was compared to the 2011 measured shoreline. Then the 2011 shoreline was specified as the initial shoreline, and each alternative was simulated for a 16 year period to predict shoreline change in the future. Figure 6 shows all five initial alternatives with Alternative 0 . Like the plots in the Figures 4 and 5 , the black lines represent 3 Mile Cut and MCR. The black, dashed lines represent the locations of the groins in Alternative 1. Since the different alternatives have different spacing configurations, the locations of the groins are different. For example, the last groin in Alternative 4 is much further south 
than the last groin in Alternative 1. The shoreline accretes between 34 and $71 \mathrm{ft}$ at 3 Mile Cut. Alternative 5 results in the greatest shoreline advance $(115 \mathrm{ft})$ at the first groin and the greatest retreat ($167 \mathrm{ft}$ ) southwest of the last groin. Alternative 2 has the least effect on the shoreline in the vicinity of the groins. Figure 7 shows the shifted alternatives. The dashed, black lines represent the locations of the shifted groins in Alternative 1. Shifting the groins to the southwest decreases the amount of shoreline advance at 3 Mile Cut for all of the alternatives. Again, Alternative 5 results in the greatest accretion northeast of the first groin $(151 \mathrm{ft})$ and the most erosion to the southwest of the last groin $(-170 \mathrm{ft})$. All of the alternatives result in accretion at the northeastern groins and erosion at the southwestern groins. The shoreline directly to the northeast of MCR builds up for all of the alternatives, including Alternative 0 . To the southwest of MCR, the calculated shorelines of some of the alternatives are slightly different from Alternative 0 , but the effect is very minor.

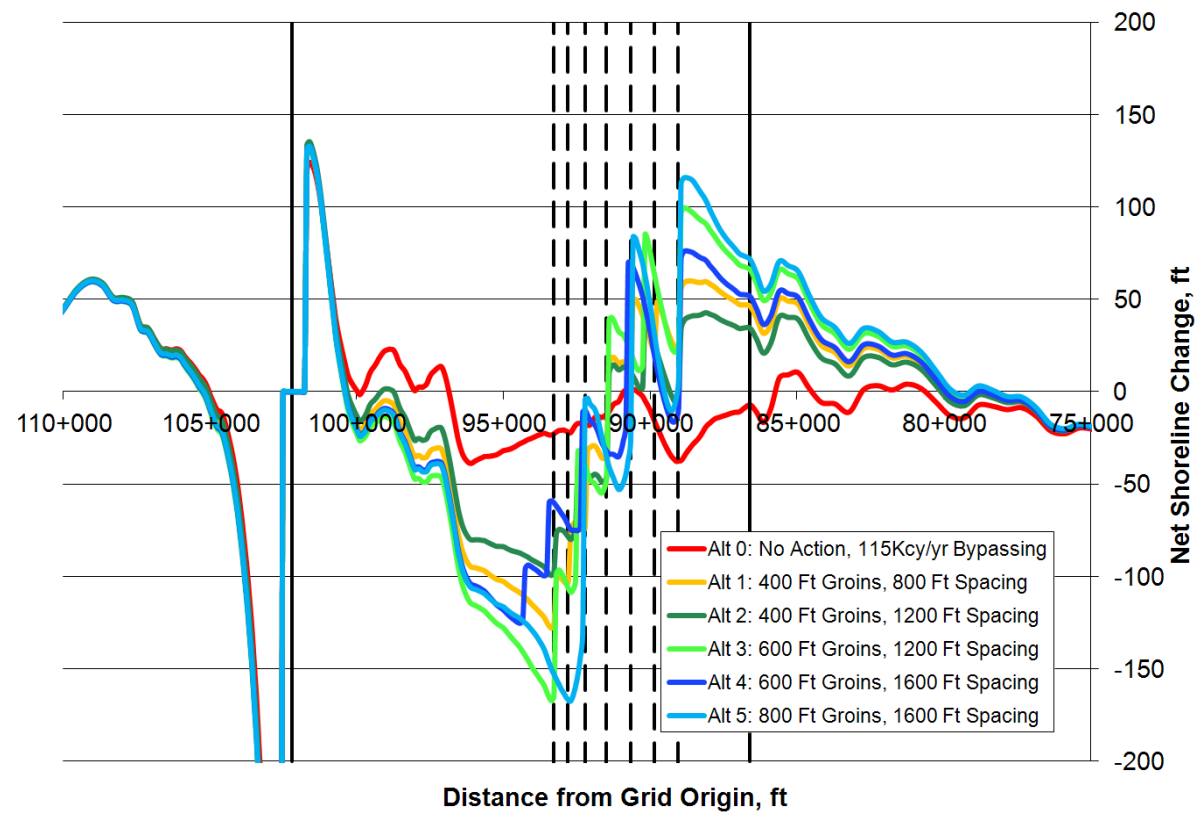

Figure 6. Shoreline change for Alternatives 1-5 after 16 years.

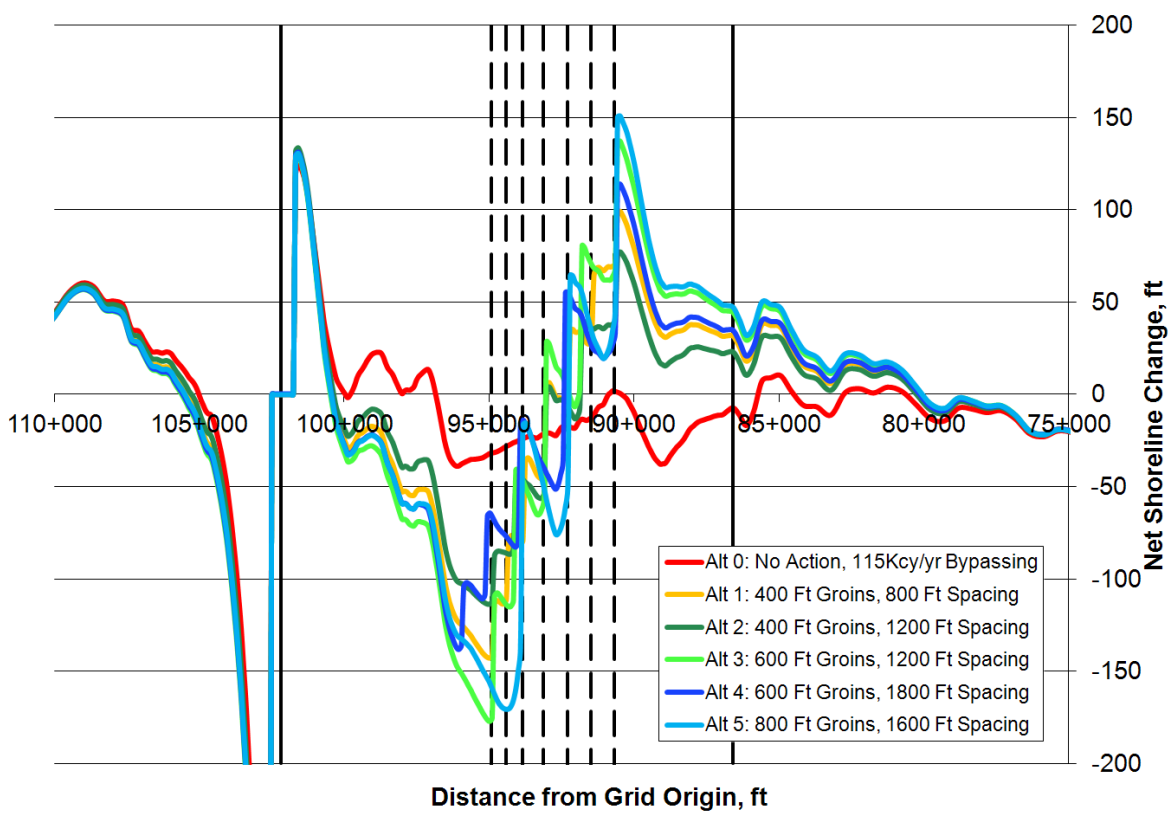

Figure 7. Shoreline change for Alternatives 1-5 Shifted after 16 years. 
Alternative 5 Shifted was selected as the final alternative at Matagorda Peninsula for preliminary engineering design since it results in the greatest shoreline advance at the first groin and the design requires the least number of groins. Figure 8 shows the grid and configuration of Alternative 5 Shifted. The green line represents the initial shoreline, and the red circles represent wave gauges. The inset shows the groins in more detail (in blue).

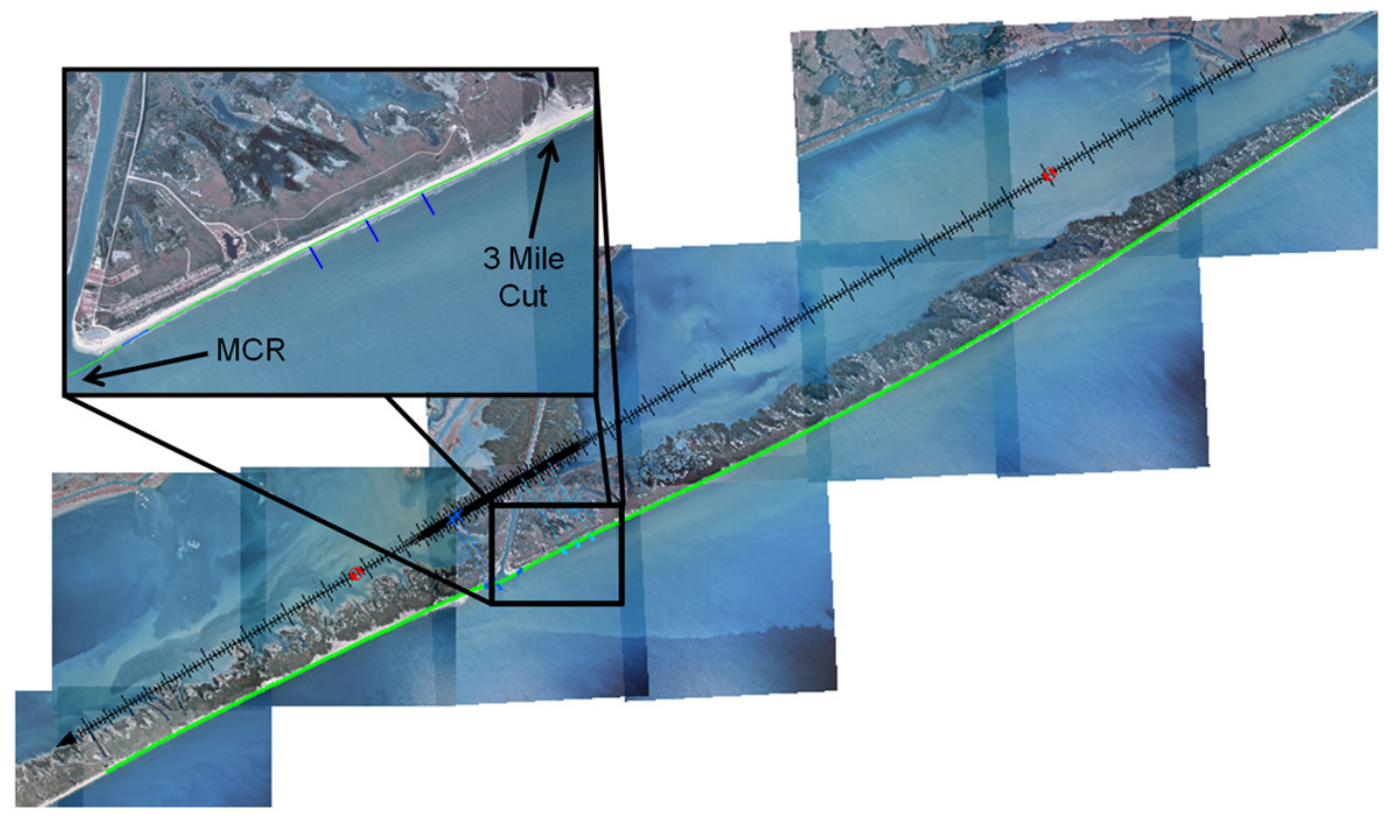

Figure 8. Groin configuration and grid setup in GenCade for Matagorda Peninsula.

Alternative 5 Shifted in Figures 6 and 7 includes 115,000 cubic yards per year of bypassing around MCR but does not include any beach fills. Although Alternative 5 Shifted most closely meets the goals of the project out of all of the alternatives, it does not meet every goal. Since mechanical bypassing is costly, it is not guaranteed that the recommended rate will occur. Therefore, the bypassing rate around MCR was adjusted from 0 to 200,000 cubic yards per year. A $200 \mathrm{ft}$ wide beach fill was placed on the beach in the vicinity of the groins in some of the scenarios. These non-structural combinations ( 0 cubic yards per year of bypassing and no beach fill, 0 cubic yards per year of bypassing and $200 \mathrm{ft}$ wide beach fill, 200,000 cubic yards per year of bypassing and no beach fill, and 200,000 cubic yards per year of bypassing and $200 \mathrm{ft}$ wide beach fill) represent the four additional cases for Alternative 5 Shifted shown in the figures below. These variations of Alternative 5 Shifted bound the results, so that any rate of bypassing up to 200,000 cubic yards per year and any added beach fill width of $200 \mathrm{ft}$ will result in a shoreline change between the shoreline changes shown in Figure 9 and 10. The Alternative 0 shown in Figures 9 and 10 does not include any mechanical bypassing around MCR, so the shoreline change is slightly different from Alternative 0 in the figures above. Figure 9 shows all four scenarios of Alternative 5 Shifted after five years. The case with a $200 \mathrm{ft}$ wide beach fill and no mechanical bypassing results in the greatest shoreline advance over the entire stretch from 3 Mile Cut to MCR. Bypassing at MCR has little effect on shoreline change northeast of second groin. In addition, all four scenarios result in shoreline advance to the northeast of the second groin. The case with 200,000 cubic yards per year of bypassing and no added beach fill results in shoreline erosion to the south of the second groin while the case with 200,000 cubic yards per year of bypassing and a $200 \mathrm{ft}$ wide beach fill experiences shoreline erosion to the southwest of the third groin. Although the case without mechanical bypassing and without a beach fill experiences slight erosion to the southwest of the last groin, the majority of the shoreline between 3 Mile Cut and MCR accretes over the five year period. 


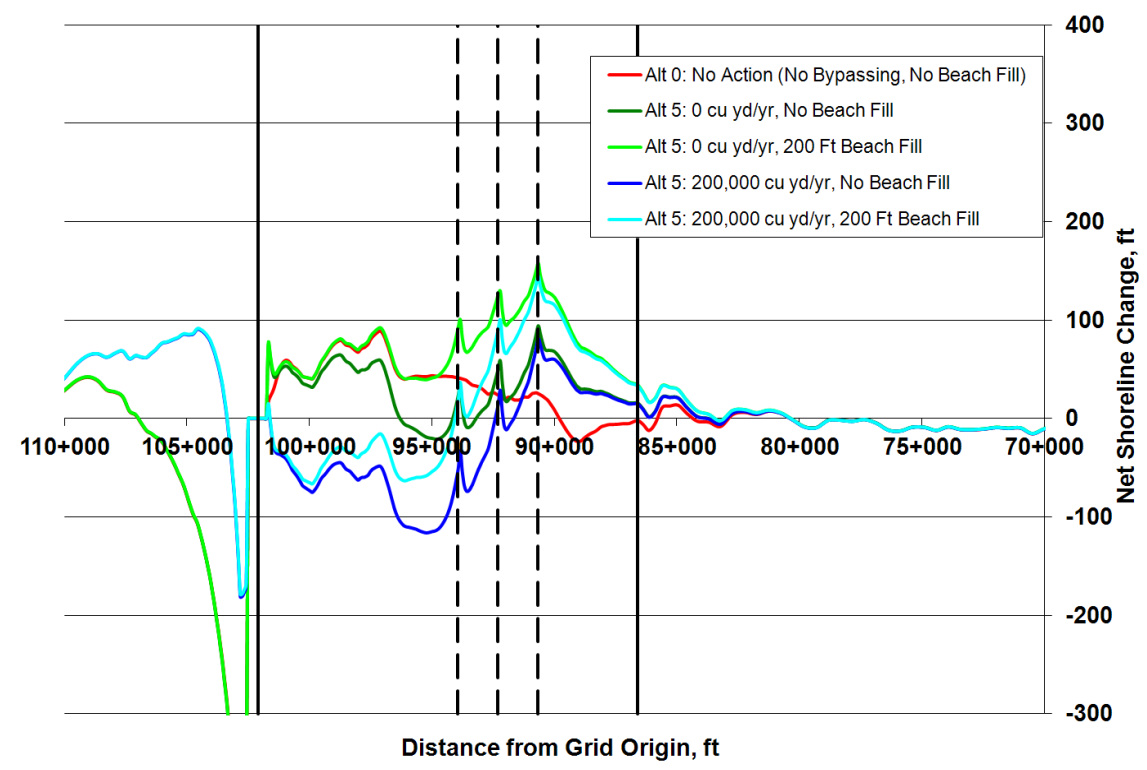

Figure 9. Shoreline change for variations of Alternative 5 Shifted after five years.

Figure 10 shows the same four scenarios after 16 years. All four cases result in shoreline advance from just northeast of 3 Mile Cut to the second groin. Regardless of whether or not a beach fill is constructed, shoreline erosion occurs to the southwest of the second groin with 200,000 cubic yards per year of bypassing. Both cases without bypassing result in shoreline advance from 3 Mile Cut to MCR, and shoreline recession southwest of MCR. The cases with bypassing experience about $100 \mathrm{ft}$ of shoreline accretion to the southwest of MCR. Alternative 0 (no bypassing and no beach fill) also experiences shoreline accretion over the entire stretch between 3 Mile Cut and MCR. However, the sand is prevented from bypassing around to the other side of the inlet which causes a large amount of erosion to the southwest of the inlet and accretion to the northeast. Based on this modeling effort, some amount of bypassing around MCR must take place, or the shoreline to the southwest of the inlet will experience substantial erosion. If too much is bypassed annually, sand will be lost to the northeast of MCR and accumulate to the southwest. Therefore, monitoring is needed to help determine what bypassing rate and beach fill volume are ideal.

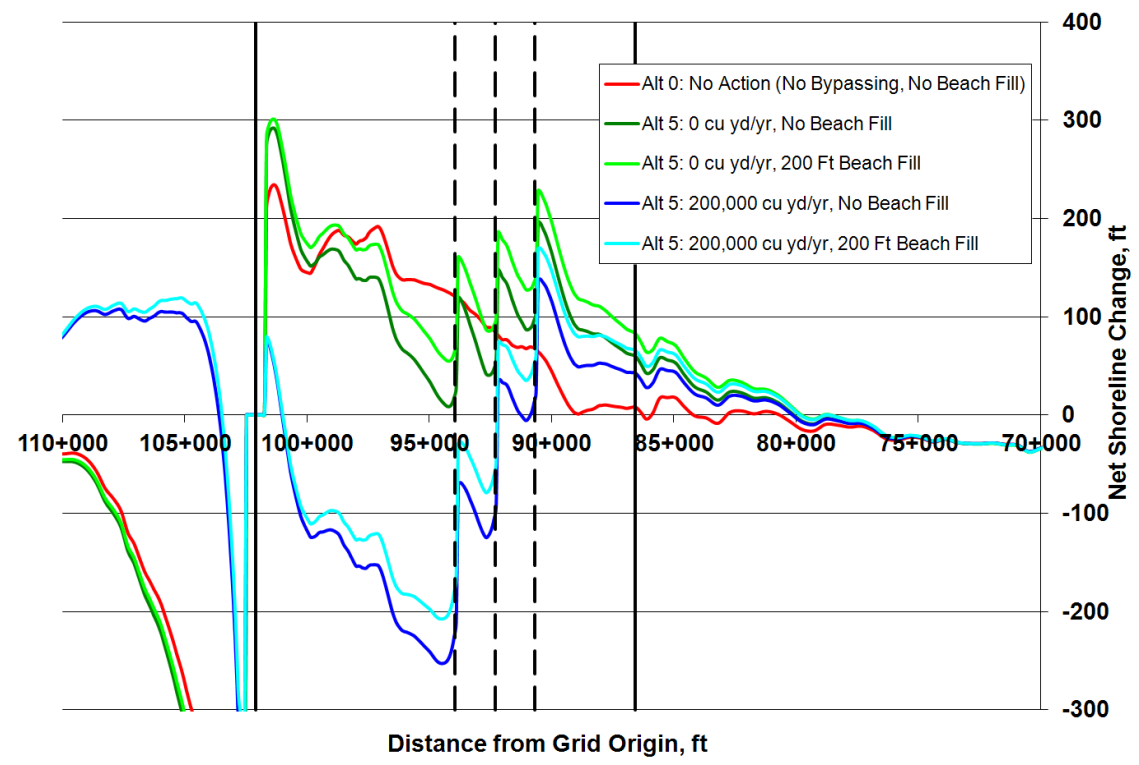

Figure 10. Shoreline change for variations of Alternative 5 Shifted after 16 years. 


\section{Sargent Beach}

The main goals of the Sargent Beach project are to protect the beach habitat and the GIWW. Initially, several different structural and non-structural alternatives were simulated with GenCade. Then the selected alternative was refined in another set of simulations.

The GenCade grid for the Sargent Beach alternatives extends from just over 5 miles southwest of the Brazos River to about 3.5 miles southwest of Mitchell's Cut. The total length of the grid is about 16 miles. Each of the grids requires a more refined grid resolution in a different location, so none of the grids have the same number of cells. The largest cell size is $490 \mathrm{ft}$ for all of the cases. The smallest cell size for the groin alternative is $164 \mathrm{ft}$ while the breakwater alternative requires a smaller cell size of 33 $\mathrm{ft}$. Only the WIS hindcast station 73060 was necessary for these simulations. All simulations were run for the time period from 1995 to 2000.

Four alternatives and two variations of alternatives were simulated during the first phase. Alternative 0 represents a case with no action. In Alternative 1, a 3,000,000 cubic yard beach fill is placed over a 10 mile stretch in front of the Sargent Beach revetment. An unrealistically long groin is implemented in Alternative 2a to demonstrate the maximum trapping capacity. Alternative 2 includes the beach fill from Alternative 1 and the single groin. Twenty-seven groins of $600 \mathrm{ft}$ long, spaced 1,800 ft apart are simulated in Alternative 3a. Alternative 3 simulates the groin field and the beach fill from Alternative 1. In Alternative 4, 10 detached breakwaters at $400 \mathrm{ft}$ offshore are simulated. These alternatives are shown in Figure 11.
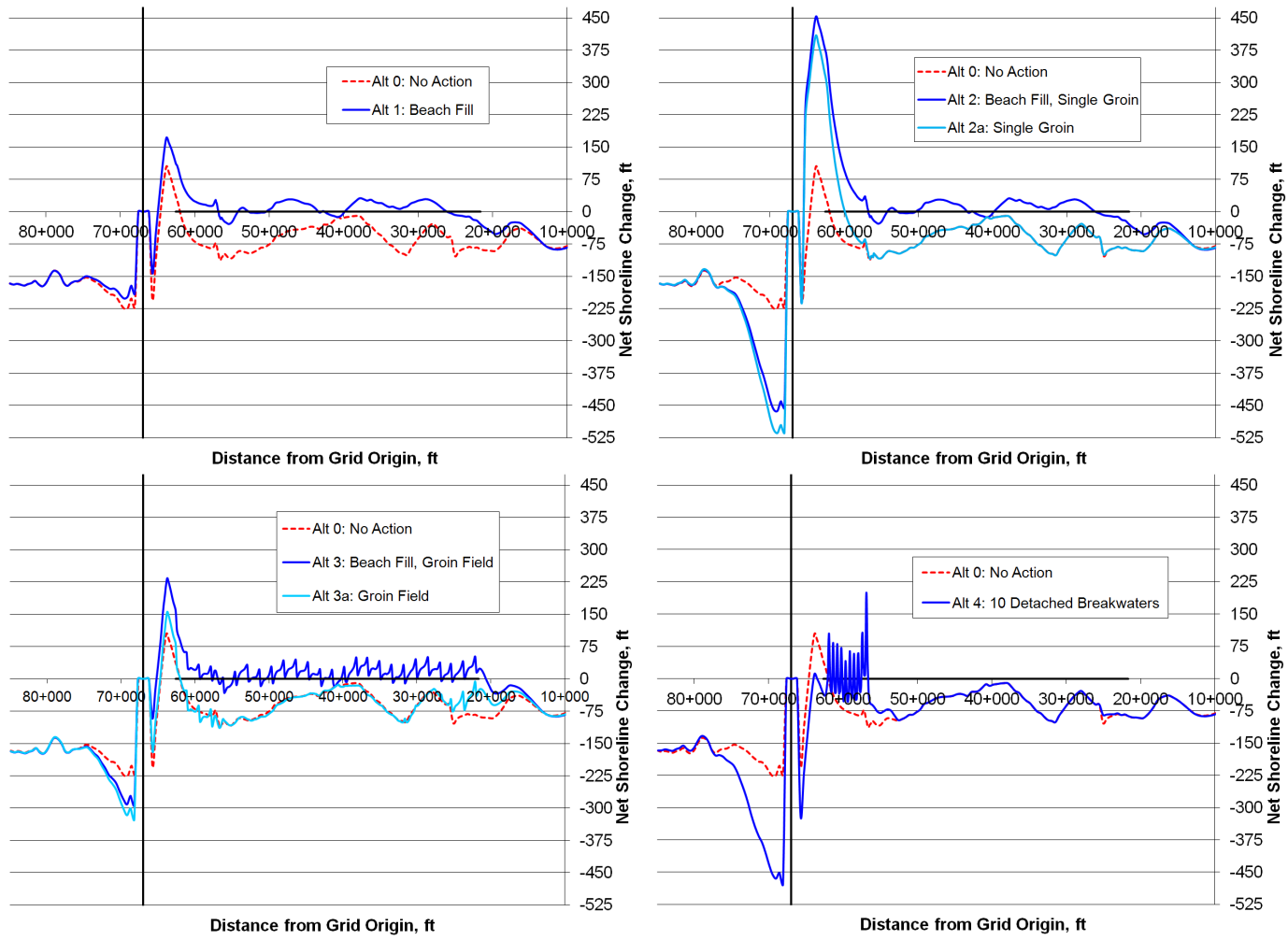

Figure 11. Shoreline change for each preliminary alternative at Sargent Beach after five years.

Each alternative is compared with Alternative 0. In all of the plots, the vertical, black line represents Mitchell's Cut and the black, horizontal line shows the limits of the revetment. With the exception of a very small stretch of shore just southwest of the revetment, the entire shoreline erodes over the five year period for Alternative 0 . Six miles of the shoreline has receded to the revetment. The 3,000,000 cubic yard beach fill in Alternative 1 results in up to $100 \mathrm{ft}$ of added beach from the Alternative 0 scenario. However, this large fill does not widen the beach; the beach is stationary at best. Even with the beach fill, the shoreline recedes to the revetment in some areas. The goal of Alternative 2 is to see the maximum trapping capacity of Mitchell's Cut. The case is run with and without the beach 
fill in Alternative 1. Although the sand accumulates to the northeast of Mitchell's Cut, the groin does not have an impact on the shoreline change northeast of about 57+000 ft. Northeast of this location, the shoreline change for Alternative 2 is identical to Alternative 1 and Alternative 2a is identical to Alternative 0 . Alternative 3 shows the effects of a groin field and beach fill on the shoreline change. However, Alternative 3a shows that only the groin field has little effect on the shoreline in front of the revetment. At the very northern end of the revetment, the groin helps protect the shoreline, but the shoreline recedes to the revetment nearly identically to Alternative 0 along most of the revetment. Alternative 4 represents a set of 10 breakwaters. The shoreline behind the breakwaters does not recede as much as Alternative 0 . At some locations, the shoreline advances after five years.

Alternatives 1, 2, 3, and 4 result in shoreline advance at some locations along the revetment. The beach fill in Alternatives 1, 2, and 3 is temporary, and after a certain amount of time it becomes necessary to renourish the fill. Additionally, it is not likely that funding will be available for such a large fill and any renourishments. Therefore, Alternative 4 was chosen as the preliminary alternative, and additional simulations were conducted.

Several variations of Alternative 4 were conducted. The breakwaters in Alternative 4 are located $400 \mathrm{ft}$ offshore and at a depth of $8 \mathrm{ft}$. Following the first phase of the study, new surveys took place which showed the water depth was shallower than previously expected. Other numerical modeling and engineering analysis was conducted which concluded that the ideal offshore distance of the breakwaters was $350 \mathrm{ft}$. Therefore, the breakwaters in the following figures are located at $350 \mathrm{ft}$ offshore and at a depth of $6 \mathrm{ft}$. Each breakwater is $220 \mathrm{ft}$ long and each gap is $330 \mathrm{ft}$. The complete project should consist of breakwaters protecting the entire 8 mile long revetment, but monitoring requirements and lack of funding render this impossible in a single construction effort. Similar to Alternative 4, the first phase represented in GenCade includes 10 breakwaters. Phase 2 consists of a total of 15 breakwaters. Since 10 breakwaters would already be in place, only 5 additional breakwaters need to be constructed during phase 2. The final phase consists of 81 breakwaters. Between Phase 2 and the Final Phase, 66 breakwaters need to be constructed. Phase 1 is shown in Figure 12. The green line is the initial shoreline, and the revetment is shown in blue. The inset provides more detail of the breakwater configuration (in orange).

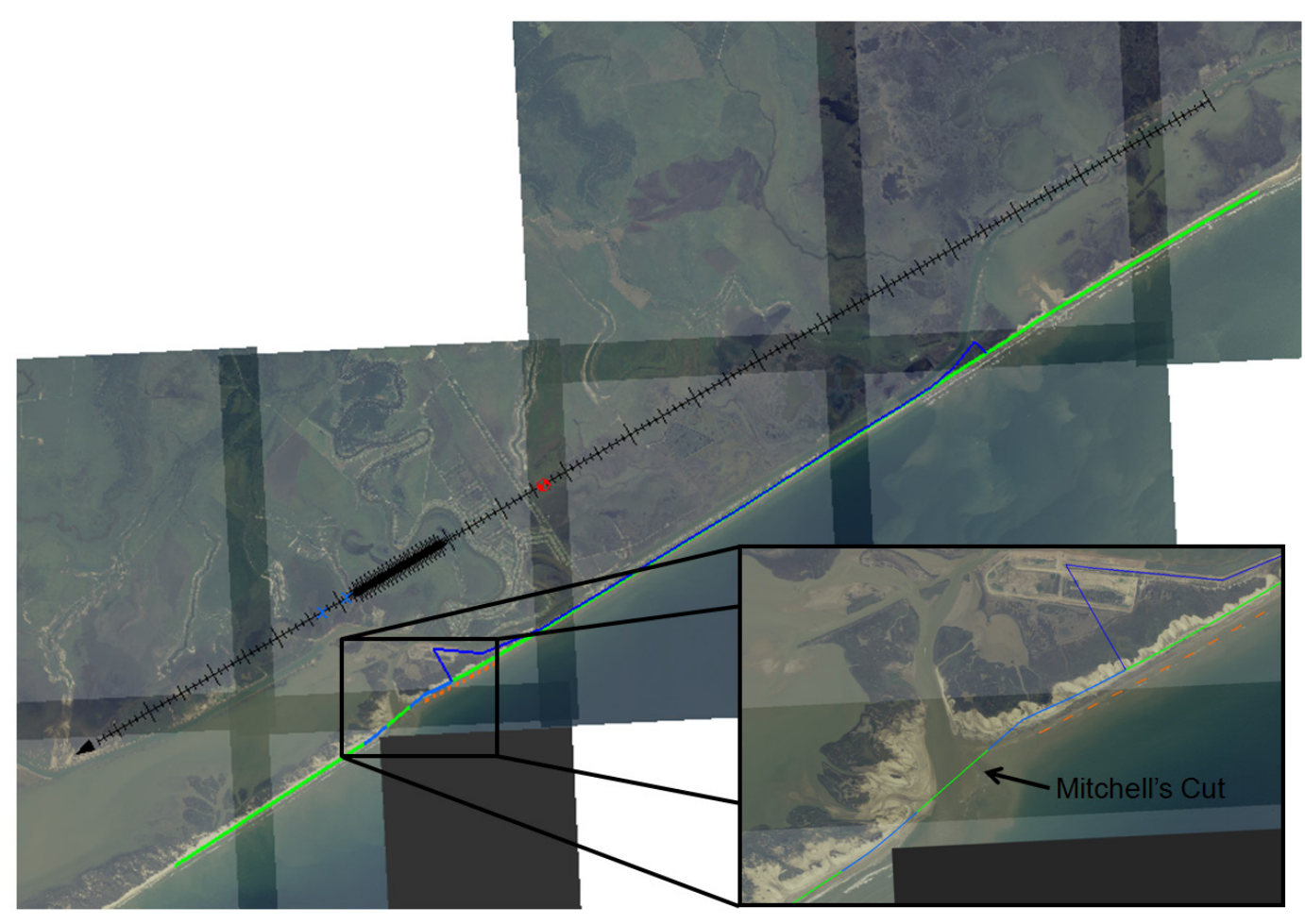

Figure 12. Breakwater configuration and GenCade grid setup for Sargent Beach. 
Figures 13, 14, 15 compare shoreline change for Alternative 0 and each phase of breakwater construction. The black, dashed lines at $350 \mathrm{ft}$ in Figures 13 and 14 represent the breakwaters. The trend in shoreline change for Phase 1 and Phase 2 construction is very similar. In both simulations, tombolos form at the first and last breakwaters. Salient formation also occurs. Both phases result in a wider beach compared to Alternative 0: No Action. If the shoreline change is averaged over the entire distance behind the breakwaters, the shoreline in both cases advances. The shoreline also advances from Alternative 0: No Action for the Final Phase case. Sand builds up to the northeast of the revetment, but the calculated shoreline erodes to the revetment at the very northeastern end. Additional erosion occurs to the southwest of Mitchell's Cut for all three phases, so a mitigation beach fill is recommended. Phase 1 results in the least erosion while the Final Phase causes the most. This is understandable, because the Final Phase traps more sand behind the breakwaters. As more breakwaters are constructed over time, more sand will need to be added to the mitigation beach fill.

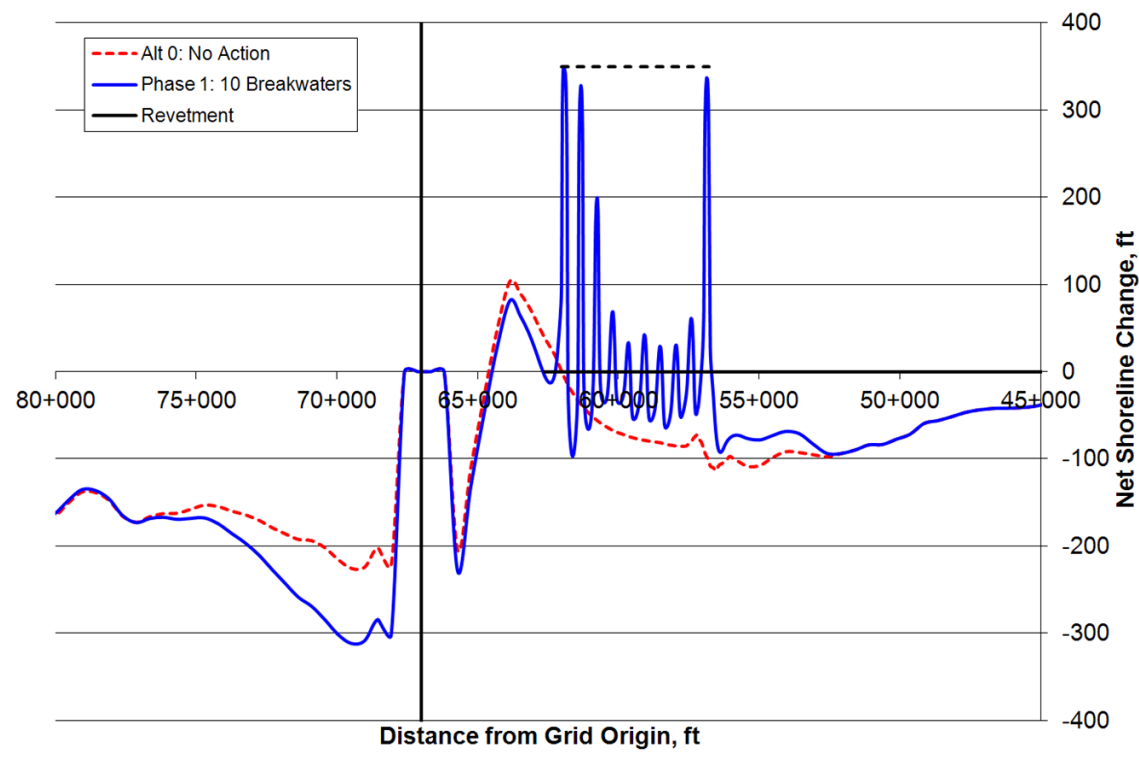

Figure 13. Shoreline change for Phase 1 Breakwaters after five years.

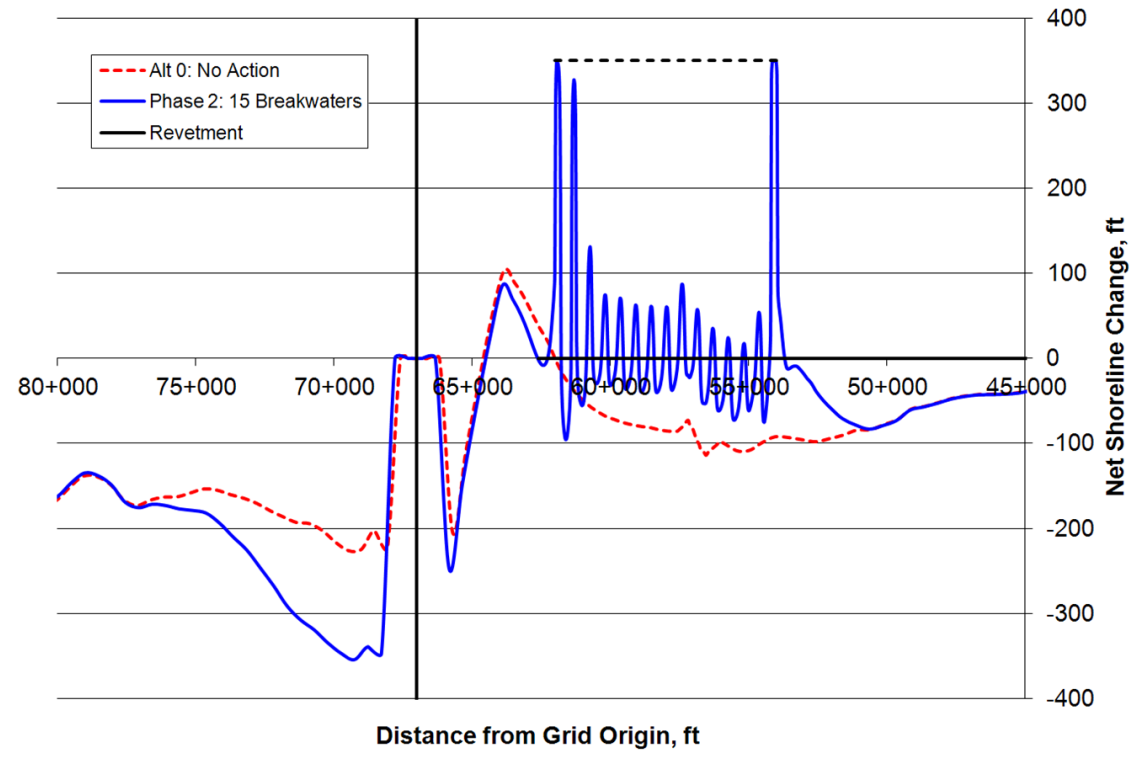

Figure 14. Shoreline change for Phase 2 Breakwaters after five years. 


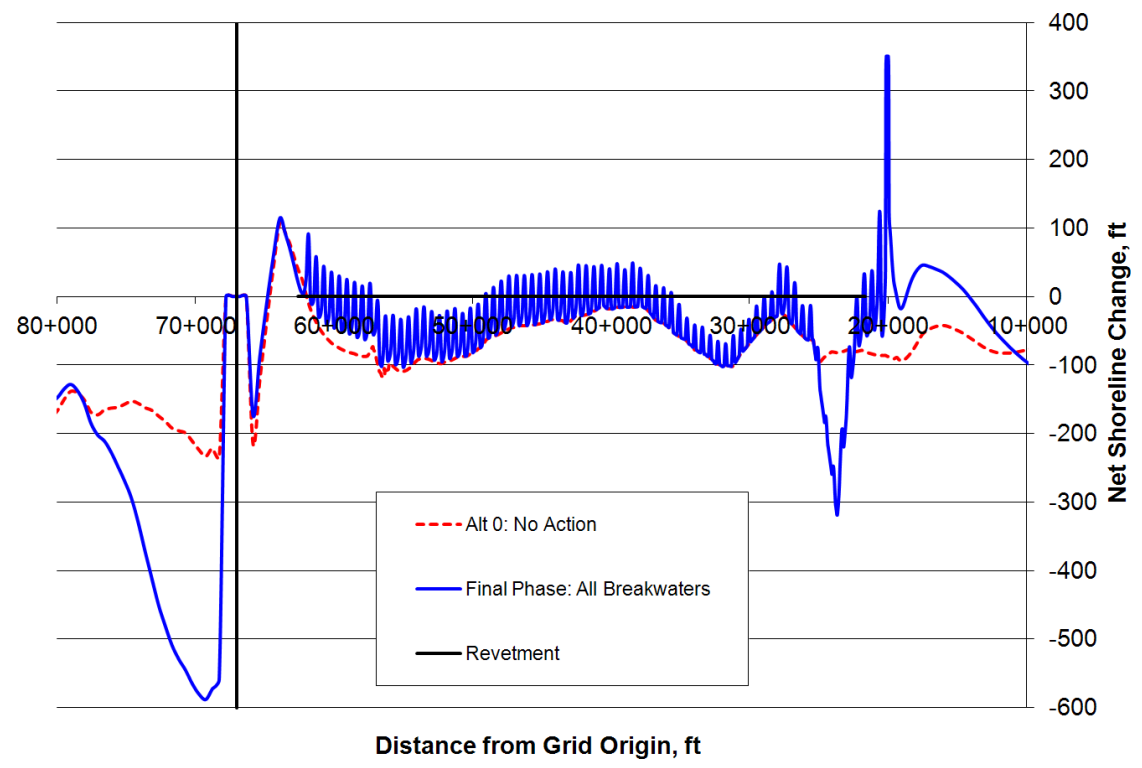

Figure 15. Shoreline change for Final Phase Breakwaters after five years.

Gross transport was also calculated for the Phase 1 breakwaters case. Figure 16 compares the gross transport averaged over five years for Phase 1 and Alternative 0: No Action. When breakwaters are not present, the gross transport rate just to the northeast of Mitchell's Cut is about 400,000 cubic yards per year. The gross transport when breakwaters are present decreases to about 225,000 cubic yards per year. A similar breakwater project was designed to trap about $50 \%$ of the longshore transport at Holly Beach, Louisiana (Mann and Thomson 2003, Mann et al. 2004, Campbell et al. 2005). The GenCade simulations show that the breakwaters in Phase 1 trap about $45 \%$ of the longshore transport.

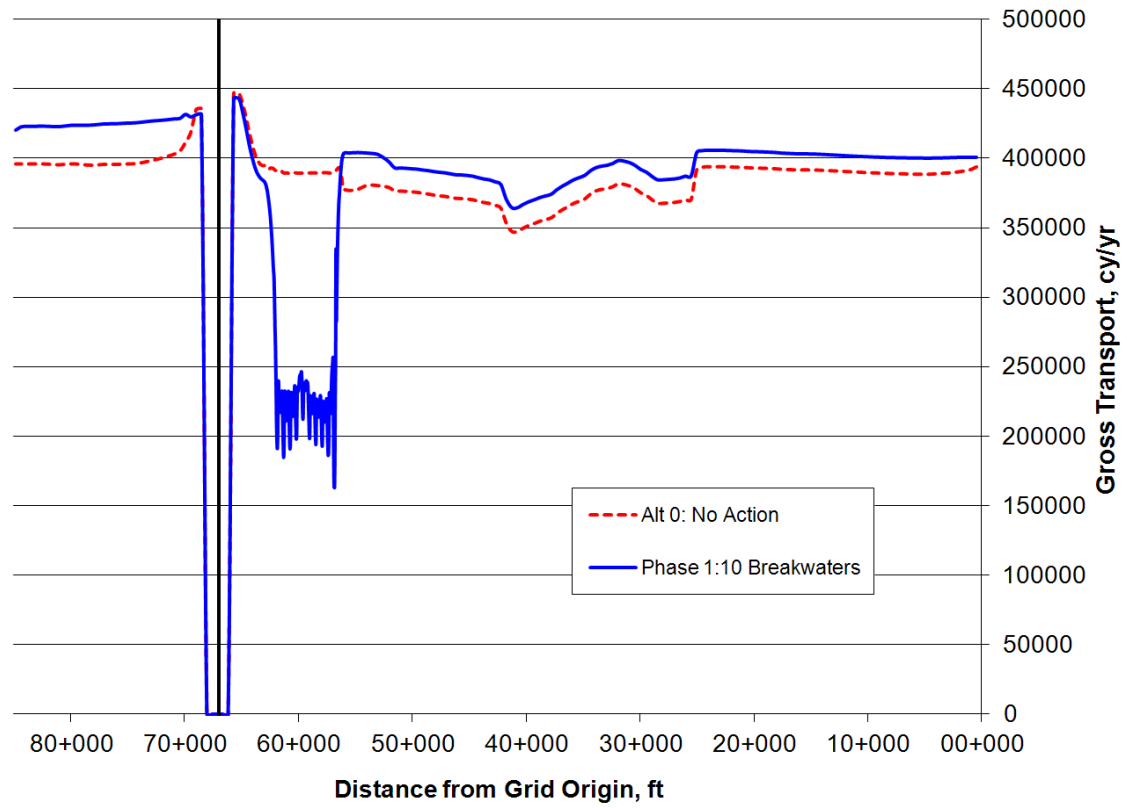

Figure 16. Average gross transport for five year simulation.

\section{SUMMARY AND CONCLUSIONS}

The main goal of the structural alternatives at Matagorda Peninsula and Sargent Beach was to halt erosion. Based on the simulations, a groin field of three, $600 \mathrm{ft}$ long groins spaced $1800 \mathrm{ft}$ apart was 
recommended at Matagorda Peninsula. GenCade also suggests that up to 200,000 cubic yards per year of mechanical bypassing would need to occur to maintain the shoreline position on both sides of MCR. GenCade showed that breakwaters were the best structural alternative at Sargent Beach. Since breakwaters are very sensitive to the coastal environment, it was recommended that the construction take place is phases. The GenCade simulations for Phase 1, Phase 2, and the Final Phase all calculated shoreline advance behind the breakwaters and reduced gross transport. Although only GenCade was described, CMS-Wave and empirical calculations were also used to recommend the alternatives at Sargent Beach. In both locations, monitoring is recommended before construction.

\section{ACKNOWLEDGMENTS}

This study was funded by the U.S. Army Corps of Engineers, Galveston District, and the Port of Bay City, Texas.

\section{REFERENCES}

Bureau of Economic Geology (BEG). 2011. Historical Shoreline Database. $<$ http://www.beg.utexas.edu/coastal/download.php> Accessed on 1 August 2011.

Campbell, T., Benedet, L., and C.W. Finkl. 2005. Regional strategies for coastal restoration along Louisiana barrier islands. In: Fink, C.W. and S.M. Khalil (eds.), Savings America's Wetlands Strategies for Restoration of Louisiana's Coastal Wetlands and Barrier Islands, Journal of Coastal Research, Special Issue, No. 44, 245-267.

Hanson, H., Connell, K.J., Larson, M., Kraus, N.C., Beck, T.M., and A.E. Frey. 2011. Coastal Evolution Modeling at Multiple Scales in Regional Sediment Management Applications. Proceedings of Coastal Sediments 2011. Miami, FL. Vol. 3, 1920-1932.

Hanson, H. and N.C. Kraus. 1989. GENESIS: Generalized model for simulating shoreline change, Report 1: Technical Reference, CERC-89-19, U.S. Army Engineer Waterways Experiment Station, Vicksburg, MS.

Kraus, N.C. 2002. Reservoir Model for Calculating Natural Sand Bypassing and Change in Volume of Ebb-Tidal Shoals, Part I: Description, CHETN-IV-39, U.S. Army Engineer Research \& Development Center, Vicksburg, MS.

Kraus, N.C., Lin, L., Smith, E.R., Heilman, D.J., and R.C. Thomas. 2008. Long-Term Structural Solution for the Mouth of the Colorado River Navigation Channel, Texas, ERDC/CHL TR-08-4, U.S. Army Engineer Research and Development Center, Vicksburg, MS.

Larson, M., Kraus, N.C., and H. Hanson. 2003. Simulation of regional longshore sediment transport and coastal evolution - The Cascade model. Proceedings of $28^{\text {th }}$ International Conference on Coastal Engineering, World Scientific Press, 2612-2624.

Larson, M., Kraus, N.C., and K.J. Connell. 2006. Cascade Version 1: Theory and Model Formulation, ERDC TN-SWWRP-06-7. U.S. Army Engineer Research and Development Center, Vicksburg, MS.

Lin, L., Demirbilek, Z., Mase, H., Zheng, J., and F. Yamada. 2008. CMS- Wave: A Nearshore Spectral Wave Processes Model for Coastal Inlets and Navigation Projects, ERDC/CHL-TR-08-13. U.S. Army Engineer Research and Development Center, Coastal and Hydraulics Laboratory, Vicksburg, MS.

Lin, L., Demirbilek, Z., Thomas, R., and J. Rosati III. 2011. Verification and Validation of the Coastal Modeling System, Report 2: CMS-Wave, ERDC/CHL-TR-11-10, U.S. Army Engineer Research and Development Center, Coastal and Hydraulics Laboratory, Vicksburg, MS.

Mann, D.W. and G.G. Thomson. 2003. Beach nourishment at the Holly Beach, Louisiana Breakwater Field, Coastal Sediments '03 Proceedings. CD-ROM.

Mann, D.W., G.G. Thomson, C. Perkinson. 2004. Structural Rehabilitation of the Holly Beach Louisiana Breakwater Field. Coastal Structures '03 Conference Proceedings. ASCE. 1135-1141.

Stauble, D.K., Hubertz, J.M,. Hoban, R.J., Livingston, C.R., Pollock, C.E., and D.R. Levin. 1994. Coastal Studies on Support of Sargent Beach, Texas, Erosion Control Project, Miscellaneous Paper CERC-94-3, Waterways Experiment Station, Vicksburg, MS.

Thomas, R. and L. Dunkin. 2012. Erosion Control and Environment Restoration Plan Development, Matagorda County, Texas, ERDC/CHL TR-12-11, U.S. Army Engineer Research and Development Center, Vicksburg, MS. 
Wave Information Studies (WIS). 2011. Gulf of Mexico Stations 73053, 73055, 73058, 73060. <http://wis.usace.army.mil/hindcasts.shtml> Accessed 1 September 2011. 